\title{
Leadership characters in shadow puppet show
}

\author{
Junaidi \\ Department of Puppetry, Faculy of Performing Arts, \\ Institut Seni Indonesia Yogyakarta, Indonesia
}

Received: November 5, 2016. Revised: March 19, 2017. Accepted: November 18, 2017

\begin{abstract}
Good leadership characters have been conveyed through the art of puppet. However, in practice, many of us have encountered the opposite fact. This study aims to analyze the leadership characters in the art of puppet. This research is a descriptive qualitative research which uses hermeneutical method to analyze the data gathered from the library research and field study. The data then passes data reduction step, data classification, and data verification. The results show that leadership characteristics in puppet can be formulated into five leadership concepts: (1) dwikridha, (2) tripakarti, (3) caturtama, (4) pancapratama, and (5) hasthabrata. If these five concepts of leadership are known, understood, and done well, our beloved country, Indonesia, will reach welfare together.
\end{abstract}

Keywords: character; leadership; shadow puppet

How to Cite: Junaidi. (2017). Leadership characters in shadow puppet show. Harmonia: Journal of Arts Research And Education, 17(2), 181-189. doi:http:/ / dx.doi.org/10.15294/harmonia.v17i2.7731

\section{INTRODUCTION}

The leader, called pangarsa in Javanese, is a figure who is believed to be the holder of power in a government or organization. Therefore, how good the leadership of an organization or government depends on the ability of the existing leadership figures in determining and implementing various policies.

The normative concept of good leadership will take a leader in creating the idealism of welfare and peace of the nation and state so that life which is prosperous or panjang (famous), punjung (flattered), pasir (beautiful), wukir (strong), loh (fertile), jinawi (easy), gemah (lively), ripah (bustling), karta (rich), tata (regular), and raharja (safe) can be achieved.

To achieve the organization goals, leadership is a process of influencing, motivating, and improving the behavior of people in the organization in achieving their group and cultural goals. Even more broadly than the process, a leader is expected to be able to influence the interpretation of his followers, organize activities in achieving goals, and maintain the support and cooperation with people outside the group or organization (Rivai, 2007).

In the current era of reform, Hayat (2014) states that a good leader will take concrete action in managing the government and in changing the culture with an effective and efficient approach. Effectiveness and efficiency are demonstrated by their ability to perform good, accountable, transparent, realistic, and participatory relationships. In this context, a leader must be sensitive to the organizational environ-

\footnotetext{
${ }^{\boxplus}$ Corresponding author: Jl. Parangtritis Km 6,5, Sewon, Bantul, Panggungharjo, Yogyakarta, 55188

E-mail: junaidi.skar@yahoo.com
} 
ment, and able to translate into bureaucratic reform principles and implement them professionally.

The issue of leadership becomes very important if it is associated with some cases of deviating acts done by our leaders. For example, the corruption cases, handled by the Corruption Eradication Commission (KPK), have involved leaders from various level of institutions. Such acts would not have occurred if the existing leaders clung to the principles of leadership.

In relation to leadership as a tool which is expected to help the organization or government achieve prosperity and peace, Hamim (2014) states that the goals of the organization will be achieved when the leader is fair, trustworthy, forgiving, flexible, compassionate to his people, wise, intelligent and honest. He further reveals that when leaders possess such traits and behaviors, the people will respect and love the leaders, the leaders will become exemplary figures, and eventually corruption and the abuse of authority will be minimized.

Rasim (2014) states that the existing leadership typology in the world can basically be grouped into hard power and soft power. Hard power leader had lasted for centuries and reached its peak in the era of World War I and World War II. In the next decade, the leadership typology began to switch to soft power type. Leaders with soft power tend to put democratic rather than authoritarian principles forward. In the context of leadership in Indonesia, he states that the ideal type is expected to be soft power that is equipped with four basic characters that are capable of bringing change, visionary, competent and based on faith and piety. In connection with these issues, this article will examine the characteristics of leadership that exist in the puppet as a work of art that reflects the local wisdom of our society.

\section{METHOD}

This is an analytical descriptive research on qualitative data, using hermeneuti- cal method, a way to interpret a problem when the interpreter examines the subject (Palmer, 2005). Data is collected by literature study strategy which is done by reading books, manuscripts, and puppet manuscripts from various regions. Besides, it is supported by direct field observation of puppet show activities, and discotheques (observing puppet shows through audiovisual cassettes of recordings of the show). Various data collection strategies are done to obtain the main data about the characteristics of leadership in the puppet either at the time of catur/ narration or conversation (janturan and ginem), tembang/ singing (sulukan), sabet/motion (tancepan and solah), and bleger/harsh form (praupan and pawakan). The research passes the following steps: (1) data reduction; (2) data presentation; and (3) data verification (Miles \& Huberman, 1992).

\section{RESULTS AND DISCUSSION}

\section{The Concept of and Leadership Technique of Dwikridha}

The word dwikridha is composed of two basic words, that is dwi means two, and kridha means to act or to work. Dwikridha in this context are the two virtues of thought and action to be performed by a king/ nata/naréndra, i.e. verbal performance like the sound/vocal produced by mouth to promise, and physical act like power and hand/giving. Both depart from a thought and a feeling that leads to a physical and material action to expend words and give something of their own ideas and property to others. Good leadership orally is called bawaleksana, meaning that what is spoken can be done (consequent), while through the hand is called bèrbudi, meaning always give (generous). Both of these traits as the hallmarks of a king or leader in dwikridha text are expressed in words and sentences explicitly in the form of fragments of janturan jejer and verse of pathetan Lasem on sabrang alus scenes in the purwa shadow puppet shows, as follows.

Dhasar naréndra bèrbudi bawa leksana, liré bèrbudi hanggung hanggeganjar ngulawi- 
sudha, bawa leksana hanetepi pangandika. (King who has a generous and consequent nature, ie always gives and appreciates his people, consequent for his words) (Junaidi, 2012).

Déné utamaning nata, bèrbudi bawa leksana, liré bèrbudi mangkana, lila legawa ing driya, agung dènnya paring dana, anggeganjar saben dina, liré kang bawa leksana, antetepi pangandika.

(The meaning of king as the main character is that it has the character of generous and consequent, that is the alms and proper speech )(Junaidi, 2012).

Generous and consequent are considered to be a moral identity for a good king or leader so that the words are not applied to the king in general, but only devoted to kings with good character, such as King Krishna, King Puntadewa, King Matswapati, Prabu Rama, King Pandu, and others. Except on janturan jejer, these words are spoken because it means a new-born baby is still clean so that any king who appeared in this first scene is given the words 'bèrbudi bring leksana'. As for the king in the sabrang scenes, the words are not applied to the kings with bad attitude, such as: King Baranjana, Prabu Sindungarba, Prabu Ravana, and so on.

The implicit and explicit meaning from the puppets cannot be used as absolute source as we need to see its relation with other signs. For example, the relation of the sign is expressed in a rough form (bleger), posture or position (pacaking awak), facial expression or facade (praupan), speech or narration (catur), and action or movement (sabet). The form, attitude, and speech for the 'bèrbudi bring leksana' king is depicted through the shape of lencir/lean body showing that the person deliberately reduces eating/preventing dhahar (meditation), attitude or body position njujur / straight and open hands giving the impression of courtesy/lembah manah (alusan), handsome black face giving calm and dignity impression, and alon-lirih/gentle speech giving careful impression.

On the contrary, the attitude and the utterance of 'nir bèrbudi bawa leksana' king will be lemu/fat showing that the figure likes to eat/nguja dhahar (greedy/dremba), body position with tangan malangkerik/ hand on waist and holding/nggegem giving impression that the person is arrogant and stingy (umuk lan uthil), and ugly red face and emotional (fierce lan brangasan), and harsh speech showing rude. For example, the appearance, attitudes, and utterances of the consequent and generous kings displayed on the figure of King Krishna and Prabu Rama. While the giant king who is stingy, lying, greedy, and congkak/uthil, goroh, srakah, lan umuk displayed on the figure of King Baranjana and King Ravana. These characteristics in the appearance of puppets, at the time of janturan, and ginem can be seen in the following pictures and quotations.

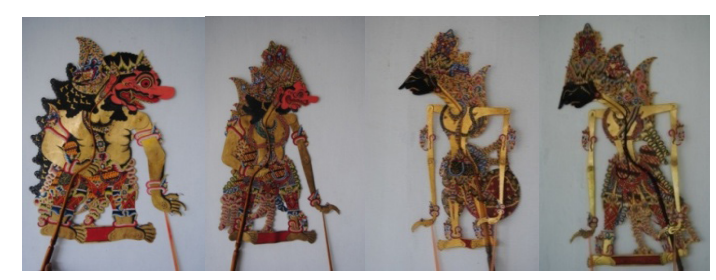

Figure 1. The ugly king of Prabu Baranjana from Jongbiraji (left) and Prabu Ravana from Alengka (second from left) and the king with good character Prabu Krishna from Dwarawati (second from right) and Prabu Rama from Ayodya (right)

... sirna kamungsané katon kadi Sanghyang Wisnu ngéjawantah dènayap para widadari. ... hanetepi bèrbudi bawa leksana, bèrbudi tansah ngganjar ngulawisudha, bawa leksana, punapa ingkang sampun kadhawuhaken boten kénging oncat, mesthi kalampahan... (Nojowirongko, 1960)

(... the disappearing of human beings looks like Sanghyang Vishnu descends with accompanied by the angels ... ... establishes the generous and consequent nature, the virtuous nature always provides the help of property and office, whereas the consequent nature shown by doing what has been spoken.

Radén Samba: “... upami pun Samba anandhanga dosa, dosa sakit Sinuwun anyakitana, yèn nandhang dosa pejah Sinuwun amejaha- 
na: sampun ingkang siang, sanadyan dalu, pejah gesangipun Samba sumangga ing asta kekalih...".

Raden Samba: "... if Samba is doing sins, only the king who has the right to hurt, if you accept the sin of death, you are entitled to give death: not only during the day, even at night, I am willing to accept it, life and death are really in your hands ...".

Prabu Kresna: “... munduran kaya wong nandhang dedosan angaturaké pati urip, iya ing sadurung sawisé nggonira njunjung kapraboningsun, banget panarimaningsun, ana bebasan sagalak-galaking macan, ora kolu mangsa marang anaké ... (Nojowirongko, 1960).

(King Krishna: “... your fears are like a sinner giving up life and death, before and after I receive your praise of my position, but there is a proverb, as vicious as a tiger, he/she will not bear to eat his own child ....

... Prabu Baranjana, ageng inggil pindha prabata, nétra lir péndah surya kembar, grana pindha canthiking baita, tutuk kadya lènging guwa, siyung mingis gumilap, waja rangah kadya parang curi ... yèn segu kaya gludhug, petak kadya gelap nyamber... (Nojowirongko, 1960).

(... King Baranjana, as tall as a mountain, eyes like twin suns, living like a boat's end, open mouth like a cave, sharp pointed fangs, pointed teeth like rocks ... the sound of burping like a thunderbolt, the sound of roar like a thunderbolt ...).

Prabu Baranjana: “... manawa wis ana pacangané, aturana murungaké, yèn wus kebanjur dhaup aturana megataké, sepira ragadé iku ingsun kang mbalèkaké, kon nyukup karsaningsun iki dhisik" (Nojowirongko, 1960).

(Prabu Baranjana: “... if you have a boyfriend, tell him to foil, if they are already married, tell them to divorce, how much it will cost me to return, order to carry out my will first).

Prabu Dasamuka: "Éblis laknat, ya bandhaku, ya donyaku, ya amal-amalku dhéwé. Thèkmu thèkku, thèkku, thèkku dhéwé. Jit yèn kowé bisa kelakon andhustha
Dèwi Warasembadra, nyata anak lanang tenan... (Siswoharsojo, 1991).

(King Dasamuka: "cursed Iblis, my property, my world, all are mine, yours is mine, while mine belongs to me. If you can steal Dewi Warasembadra, you are a truly man ...).

The excerpts of janturan and ginem above have a positive and negative meaning to the good and bad character of the king depicted by his physical form, nature, and speech. The positive meaning is depicted through the handsome King Prabu Krishna figures and beautiful bodies like Batara Wisnu, who like to give alms and keep their promise, so appreciating other's work and achievements is very preferred. The nature of this king sees others on their good deeds above the bad deeds because the good has been done, while the bad deed is not done yet.

The negative meaning is the opposite of the positive meaning, which is shown by bad appearance and characters, as a picture of the arrogant leader, for imposing his will on others without introspection on him. For example, King Baranjana, the king of of Jongbiraji and King Ravana, the king of Alengka. These two kings, unsuccessful in leading the country and its people, suffered enormous loss, which received a futile death, a ruined state, and suffering people because of his arrogance and greed.

\section{The Concept of and Leadership Technique of Tripakarti}

The word tripakarti means three deeds that must be done by a king, so as not to be underestimated by his people, namely: (1) hamong, meaning nurturers, (2) hamot, meaning broad-minded, (3) and hamemangkat, meaning appreciate the ability of others. These leadership traits are taught by Begawan Kuntawibisana to his son King Prabu Bisawarna, in order to be respected as king in Singgela.

Hamong is a manifestation of the care of the king to the punggawa and his people like his own son, so as to create a good family relationship like parents with their children. Hamot is the embodiment of the 
breadth of views or mind, in order to receive and accommodate a wide range of ideas so that the decisions they make will be accepted by the community. Hamemang$k a t$ is a manifestation of appreciation for the services of others in order to create a competing atmosphere in doing good and useful things for the nation. This character model is picked from ginem or dialogue of Begawan Kuntawibisana with his son Prabu Bisawarna at Candramanik hermitage, as follows.

Prabu Bisawarna: "Kanjeng Rama, kados pundi sagedipun kula tansahkinèringan déning para wadya-bala, para sénopati, tuwin para brahmana, kados Panjenenganipun Kanjeng Rama nalika ngesuhi praja saha kawula duking nguni, ...".

Begawan Kuntawibisana: " ... supaya nora dicecamah déning para wadya. Marmané kulup, élinga welingé si bapa ya nggèr, jumeneng ratu mono kudu sing bisa hamong, hamot, hamemangkat (Wignyosoetarno, 1996).

(Prabu Bisawarna: "Father, how can I always be respected by the courtiers, senapati, priests, like when you led the nation in the past, ...".

Begawan Kuntawibisana: “... so as not to be insulted by the punggawa. Look, son, remember your father's message, son, as the king must be able to nurture, listen, and respect").

The tripakarti leadership traits are obtained by the king through a quest or learning. King Bisawarna, as the definitive leader, is always respected or appreciated by the courtiers, senapati, priests in Singgelapura, with full awareness to seek guidance to his father, Begawan Kuntawibisana (the former leader). His father adviced me to behave and act as a caregiver like his own sons and daughters, holding various elements, and elevating others.

In this context, a leader serves as a guide, educator, patron, unifier, and observer for his nation, which also means that he/she should have an awareness of his/ her shortcomings (awareness/nglenggana/ ngakoni/ ngrumangsani), so he/she must keep learning and always try to do good for the country (effort/change/mbudidaya/ sinau) with affection (ratu Asih/full of love king). Leaders' awareness and change to good can create peace and sustainability. The meaning is realized through the looks of Prabu Bisawarna and Begawan Kuntawibisana (bagusing pasuryan lan lencir kuninging salira) and the good contents of the talk (apiking isi gineman).

The good characters of this leadership are opposite to the negative leadership traits of Prabu Dasamuka from Alengka, which is kuwasa or authoritarian (using his power), béda or discriminate (relying on his own strength), and dhendha or like giving punishment (relying on self-righteousness). Thus, the mighty and powerful king Rahwana, the mighty and powerful Alengka, encountered the death and destruction from Rama's army. Thus, the noble Wibisana was appointed king in Alengka trying to improve his identity and system. The name of the Alengka was changed to Singgela, while the leadership system of kuwasa, béda, and dhendha became hamong, hamot, and hamemangkat. This change is the fruit of goodness, namely glory, majesty, and peace of Singgela up to Pandawa era. For example, in the play Partakrama, King Prabu Bisawarna, the king of Singgela lend a train for the bride Raden Premadi, and Resi Anoman of Kendalisada hermitage as the carriage driver. The illustration shows the difference of the appearance and character of the leader in Alengka and Singgela which can be seen in the figure of the two characters.

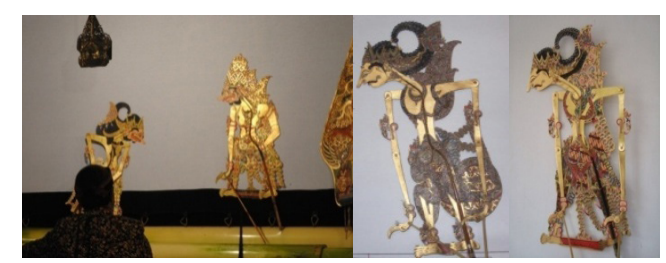

Figure 2. The appearance of the ugly ruler of King Prabu Ravana from Alengka and the crown prince of Raden Indrajid (left) and the king of good character Prabu Bisawarna, king of Singgela and Begawan Kuntawibisanadi from Candramanik hermitage (Photo: Junaidi, 2016). 
The tripakarti characters can also be expressed in other terms, namely: (1) Nist$h a$, meaning that the person always wants to control others' property /melikan; (2) Madya, meaning that the person knows what should be given/ora uthil ora loma, and (3) Utama, meaning that the person is generous and consequent/bèrbudi bawa leksana. This is applied to all leaders in general, that is applicable to all kings without exception, so it is not given by certain figures and accepted by certain figures as well. Thus, the teachings of leadership for the king is freely given by the advisor to the king, such as: Resi Bisma to Prabu Duryudana, Resi Druwasa to Prabu Kuntiboja, Resi Wasista to King Dasarata, Resi Abiyasa to King Puntadewa, and so forth. It can also be conveyed in the discussions of kings, such as: King Salya, King Puntadewa, King Krishna, and King Baladewa. For example, Resi Bisma gives advice to King Duryudana not to take control of others' the property rights, namely the Amarta, as follows.

Resi Bisma: "La yèn pancèn Pandhawa wus netepi janjiné, buntas dhendha paukumané, ya kudu dibalèkaké panguwasané tumrap nagara Ngamarta marang para kadangmu Pandhawa. Iki jenengéétung gathuk tumbuk rukun ngudi rahayu ..." (Junaidi, 2012).

(Resi Bisma: "If Pandavas have fulfilled their promise, that the time limit of the sentence has been expired, it will be restored to Pandavas by the right of ownership and power over Astina to your brother, Pandavas. This is a way to get peace.

As a visual illustration, there are examples of scenes when tripakarti is taught by Resi Bisma to Prabu Duryudana and conveyed by one king to other kings: King Salya of Mandaraka to the king of Amarta King Puntadewa, king of Dwarawati Prabu Kresna, and the king of Mandura Prabu Baladewa in the show of purwa shadow puppet Banowati Janji/Kurupati RabiBanowati Krama, that is the marriage between King Duryudana with Goddess Banowati and involving Premadi as a princess masquerade. Visually seen in the form of sabetan of King Duryudana as king is displayed on tancepanpamedan (stuck on the top of banana trunk) with the position of staight hands as a shy image of Resi Bisma, while Resi Bisma stuck on top banana trunk with straight hand positions meaning as elder who respects the younger but having higher position. The illustration can be seen in the following figure.

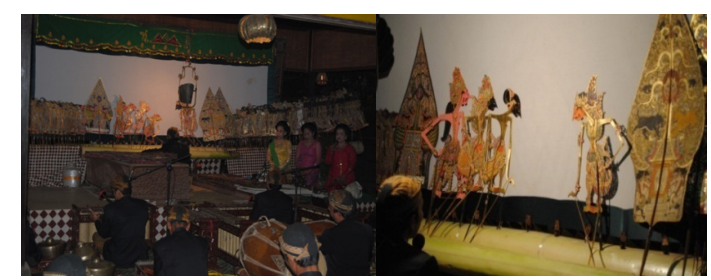

Figure 3. Scene to convey the teachings of nistha, madya, and utama by advisor or priest with king (left) and discussion material for kings as an effort to exchange thoughts (right) (Photo: Junaidi, 2016).

\section{The Concept of and Leadership Technique of Caturtama}

Caturtama means four virtues deserved by the king, namely: (1) Sama, meaning no partial decision towards the courtier and his people; (2) Bèda, meaning to understand the difference in his country; (3) Dana, meaning generous to the courtier and his people; and (4) Dhendha, meaning that it is fair to make a decision. The teachings of caturtama will create a justice king, so they deserve to earn the title as naréndra utama/ratu utam. This concept was conveyed by the king of Sri Batara Aji Pamasa or Prabu Kusumawicitra to King Gandakusuma when appointed as the king of Kartanagara and Bojonegara. Furthermore, it is shown on purwa shadow puppet show in the form of janturan jejer Dwarawati with its King Prabu Kresna in the play Irawan Rabi by Nojowirongko, Astina with Prabu Duryudana in the play Wirathaparwa by Junaidi, in the play Sudamala and Dèwi Kuntulwinanten by Purwadi, but they are not performed in the show of Prabu Duryudana from Astina in the play of Wahyu Makutharama by Wignyosoetarno, Prabu Drupada from Pancala in the play of Gandamana Sayembara, Prabu Parikesit from Astina in the play of Parikesit Wini- 
sudha, Prabu Kresna from Dwarawati in the play of Wahyu Mandéra Retna, Wisanggeni Krama by Ki Narto Sabdo.

The function of caturtama teaching is to make the leader always think and act well, that is not to give partial decision towards all punggawa and its people, understand the difference that exist in the nation, like giving aid for the needy, and fair in law (not fair in making decision). Thus, the king can run his government well in accordance with established guidelines or duties, that is as a role model and protector that always act right and wisely: paring sandhang wong kawudan/provide clothes to naked people, angsung pangan wong kaluwèn/ feeding the hungry, awèh banyu wong kasatan/ giving water to those suffering drought, paring teken wong kalunyon/ give the stick to the slipping, angsung kudhung wong kepanasan/giving veil to those suffering the sun heat, aweh payung wong kodanan/ giving umbrellas that are in rain, karya suka kang nadhang prihatin/like giving help to those need help (Nojowirongko, 1960).

The meaning of caturtama is the sensitivity and accuracy of a king to think and act which will create an atmosphere of togetherness, tolerance, fulfillment, and justice in the region. If these attitudes and actions can be done by the leaders, then his people will always live in sufficiency, so that the people will respect him more. Thus, the honor and dignity of a leader should not be formed by arrogance (kumingsun), power (kumawasa), conscience (kekuthilan), and injustice (botsih), but through a sense of togetherness (padhaajèn-ingajénan/mutual respect), difference (beda dadi sugih/ different being rich), generosity (seneng wèwèh/likes to give), and justice (jejeg/decisive). The meaning is built through the relation between the sign of the oral and visual, in the form of janturan jejer (catur/ narration) tells the nature of the king who likes to help the punggawa and his people who are suffering and tancepan (sabet/ motion) that impressed calm and polite attitude (tancep jejeg with straight hand position). The illustration can be seen in the following picture.

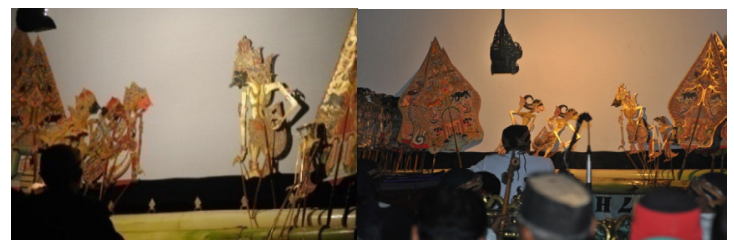

Figure 4. The position of the king of King Prabu Duryudana king of Astina with the position of malangkerik hand (hand on the waist) showing arrogance (left) and Prabu Kresna, the King of Dwarawati with straight hands showing calm and polite (right) (Photo: Junaidi, 2012).

\section{The Concept of and Leadership Technique of Pancapratama}

Pancapratama means five goodness for the king, namely: (1) Mulat, means to observe the inferior carefully (waskat = inherent supervision); (2) Milala, meaning giving rewards to the meritorious (hasa = meritorious gift); (3) Miluta, meaning familiar and close to the people (akat = close) intimate); (4) Palidarma, meaning to teach good deeds and wisdom to the punggawa and its people (bajak = good and wise); (5) Palimarma, meaning courteous and forgiving ( sama $=$ polite and forgiving). Careful scrutiny can be used as a tool to make good decisions because it is based on real and measurable facts, so the decision is based on proportional performance and reality. Giving reward for the meritorious is the good act of rewarding the meritorious to the nation. Being familiar means as a familiar attitude that can make closeness and togetherness. Teaching to do good is seen as a seed or an investment of prosperity and happiness. Forgiving is a noble and peaceful soul that can cause compassion.

The nature of supervising, giving, being familiar, educating, and forgiving is used as a medium for the welfare of the nation, so it is shown through the figure of a good king of Pandavas, like King Parikesit king of Astina after the war of Baratayuda. The meaning contained in the teachings of pancapratama is the welfare of a nation lies in its leader who has waskat, hasa, akat, bajak, and sama. The relation between ele- 
ments in puppet is on the audio/narration and visual/physical appearance. Audio in the form of caturginem of Prabu Parikesit or King Dipayana to his son Prabu Yudayana, while the visual character of Prabu Parikesit, the only son of Raden Abimanyu with Dewi Utari, who has handsome face. The illustrations can be seen in the following quotations and figures.

"Hèh putraningsun kaki Prabu, rèhné bénjang énjang sira ingsun tilar mukswa, muga èstokna kang dadi wulanganingsun ing sira; ing samengko sira iku wus pinasthi ing déwa dadya pandam pangaubané saisining rat pramundhita, poma sira anetepanaambegingratu binathara $i k u$, amung limang prakara, yaiku: mulat, milala, miluta, palidarma,lan palimarma" (Marwanto, 1977).

(Oh my son nanda Prabu, because tomorrow morning I will leave you for mukswa, then carry out my teaching, later you are predestined by gods become light and protector of the whole world, then hold on to the nature of the great king; there are five characters: careful supervision, appreciate service, familiar to subordinates, good wise, and polite and forgiving").

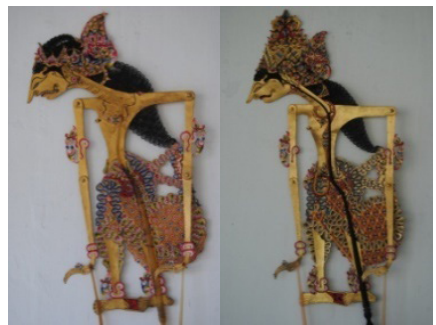

Figure 5. Raden Parikesit (left), King Parikesit (right) who taught pancapratama, having handsome face as a good character picture, the collection of Sanggar Wayang Walisanga (Photo: Junaidi, 2016).

The Concept of and Leadership Technique of Hasthabrata

Hasthabrata means eight virtues a king that must be possessed by a king, drawn through the objects of the universe, namely: (1) Surya/ sun, meaning encouraging; (2) Candra/moon, meaning entertainer; (3) Kartika/stars, meaning as markers; (4) Mendhung/cloud, meaning authoritative; (5) Bantala/earth, meaning tranquil/ safe; (6) Segara/ocean, meaning insightful;
(7) Geni / fire, meaning to have a firm principle; and (8) Maruta/wind, meaning to do everything. Hasthabrata is delivered by Sri Prabu Aji Pamasa, king of Pengging Witaradya, but in the world of puppetry, King Prabu Pamasa is a king in Kediri. The teaching of hasthabrata puppetry is given by Prabu Rama to his brother Prabu Barata, to serve as a guide or example. It is also taught by Begawan Kesewasidi to Arjuna, to be used as guidance of a king or nata/ narèndra.

The king or leader is expected to give the spirit and life energy but not expectany reprisal, like the nature of the sun. The leader is expected to be a lamp in darkness or a helper in misery, like a moon that appears at night. The leader is expected to be an example or role model for his people, like a star in space that appears as a marker of space and time. Leaders are expected to have a fruitful authority on well-being, as clouds appear to be scary but can turn into rain as a means of life. Leaders must be strong and tranquil spirit that can be used as a foundation for his people, like the earth that can sustain the various objects on it. Leaders must be broad-minded in order to accommodate views and ideas, like a vast ocean and capable of accepting things without restoring. The leader must be able to be fair in order that his decision is not onesided or unilaterally disadvantageous, like a indiscriminate fair fire. Leaders must be spiritually prevalent for all without discrimination, such as winds that can go into any places without exception.

The function of the eight guidelines for the king in this puppet show is used as an example for leaders who constantly base on eight exemplary properties of the nature of the universe so that the nation and its people will be in peace and prosperity. To achieve this expectation, a leader must be an encourager, an entertainer, a sign, a life source, a support, a container, a court, and equity, so that the courtier and his people become good-hearted and act in accordance with the order directed by the leader. With good heart and action according to the guidance or regulation, the life 
of a nation can be secure in the happiness of the world (bagya mulya donya akhérat), just like a leader in puppet show who has possessed and practiced the teaching of hasthabarata, i.e.: Prabu Rama, Prabu Barata, King Krishna, and Raden Arjuna. As an illustration is shown scenes, figures, and narrations related to the teachings of hasthabrata as follows.

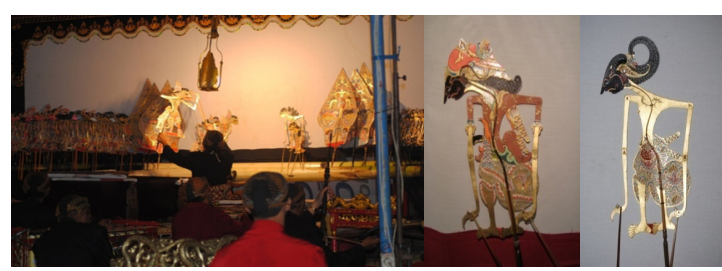

Figure 6. King Rama is giving Hasthabrata lecture to Barata in Hasthabrata Kawedhar play in scenes in Dandaka Forest (left), Begawan Kesawasidi/Prabu Kresna (middle), and figure of Raden Arjuna (Right) (Photo: Bayu, 2012) .

\section{CONCLUSION}

Based on the discussion above, it can be concluded that the leadership qualities shown in the puppets can be used as a source of education for leaders ranging from the lowest level (Head of Family) to the highest level (Head of State). In the practice of leadership, these traits as the wisdom of cultural values of the Indonesian nation can be used as a guidance in carrying out its duties in order to realize the welfare and peace of mind and soul.

\section{REFERENCES}

Junaidi. (2012). Wayang Kulit Purwa Gaya Surakarta: Ikonografi \& Teknik Pakelirannya. Yogyakarta: BP Institut Seni Indonesia Yogyakarta.

Marcel, D. (2012). Pesan, Tanda, dan Makna. Yogyakarta: Jalasutra.

Nojowirongko, M. N. A. (1960). Serat Tuntunan Pedalangan Caking Pakeliran Lampahan Irawan Rabi, Jilid I-IV. Jogjakarta: Djawatan Kebudajaan Kementerian P.P. \& K.

Hamim, M. (2014). Korelasi Antara Hasta Brata (Konsep Keemimpinan dalam Perspektif Budaya Jawa) dan Islamic leadership (Konsep Kepemimpinan dalam perspektif Islam). ULUL ALBAB Jurnal Studi Islam, 14(3), 57-68.

Palmer, R. E. (2005). Hermeneutika Teori Baru Mengenai Interpretasi. Yogyakarta: Pustaka Pelajar.

Rasim, A. (2014). Tipologi Dan Karakter Ideal Kepemimpinan Dunia. Jurnal Lingkar Widyaiswara, 1(1), 46-52.

Rivai, V. (2007). Bank and Financial Institute Management. Jakarta: PT. Raja Grafindo Persada.

Siswoharsojo. (1991). Pakem Pedhalangan Lampahan Wahyu Purbosejati. Yogyakarta: Gondolayu-Ngayogyakarta. 